Jurnal Pustaka Budaya. Vol. 7, No. 2. Juli 2020

Copyright (C2020, pISSN: 2355-1186 / eISSN: 2442-7799

Available Online at: https://journal.unilak.ac.id/index.php/pb

\title{
PENYIMPANAN ARSIP DINAMIS AKTIF DI BIDANG KEARSIPAN DINAS KEARSIPAN DAN PERPUSTAKAAN KABUPATEN PADANG PARIAMAN
}

\author{
Suci Indah Permata*), Elva Rahmah**) \\ Universitas Negeri Padang, Padang, Indonesia \\ email: scindpermt2408@gmail.com*), elva@fbs.unp.ac.id**)
}

Naskah diterima: 16 April; direvisi: 30 April; disetujui: 2 Mei 2020

\begin{abstract}
Abstrak
Tujuan dari penelitian ini adalah untuk mendeskripsikan bagaimana prosedur penyimpanan arsip dinamis aktif di bidang kearsipan Dinas Kearsipan dan Perpustakaan Kabupaten Padang Pariaman dan untuk mendeskripsikan apa saja kendala yang dihadapi oleh bidang kearsipan Dinas Kearsipan dan Perpustakaan Kabupaten Padang Pariaman dalam penyimpanan arsip dinamis aktif. Metode penelitian yang digunakan peneliti adalah metode penelitian kepustakaan dan studi lapangan yang meliputi observasi, wawancara dan dokumentasi. Hasil penelitian menunjukkan bahwa penyimpanan arsip dinamis aktif di bidang kearsipan di Dinas Kearsipan dan Perpustakaan Kab. Padang Pariaman menggunakan Norma, Standar, Prosedur dan Kriteria (NSPK) dalam Pelaksanaan Pemberkasan Arsip sebagai pedoman dalam pelaksanaan pemberkasan arsip di lingkungan Dinas Kearsipan dan Perpustakaan Kabupaten Padang Pariaman, Hal ini bertujuan memudahkan arsiparis dalam penemuan kembali arsip di lingkungan Dinas Kearsipan dan Perpustakaan Kabupaten Padang Pariaman dengan cepat, tepat, aman dan efisien. Ada beberapa kendala yang dihadapi dalam penyimpanan arsip dinamis aktif yaitu pertama, kurangnya SDM (Sumber Daya Manusia) dalam penyimpanan arsip dinamis aktif, Kedua tempat yang kurang memadai.
\end{abstract}

Kata kunci: arsip dinamis aktif, penyimpanan arsip

\begin{abstract}
The purpose of this study is to describe how the dynamic archive storage procedures are active in the archives field of the Padang Pariaman District Archives and Library and to describe what are the obstacles faced by the archives in the Padang Pariaman District Archives Office inactive dynamic archive storage. The research method used by researchers is the method of library research and field studies which include observation, interviews, and documentation. The results showed that dynamic archive storage was active in the field of archives in the Office of Archives and District Library. Padang Pariaman uses Norms, Standards, Procedures, and Criteria (NSPK) in the Implementation of Archives Filing as a guideline in the filing of archives in the Padang Pariaman District Archives and Library Service. Pariaman is fast, precise, safe, and efficient. There are several obstacles faced inactive dynamic archive storage, namely first, the lack of HR (Human Resources) inactive dynamic archive storage, Second, inadequate places.
\end{abstract}

Keyword: active dynamic archive, archive storage 


\section{PENDAHULUAN}

Arsip mempunyai peranan penting dalam proses penyajian informasi bagi pimpinan untuk membuat keputusan dan merumuskan kebijakan, oleh sebab itu untuk dapat menyajikan informasi yang akurat, tepat waktu (cepat), relevan dan lengkap, haruslah ada sistem dan prosedur kerja yang baik dalam penyimpanan arsip. Mengingat peranan arsip yang begitu penting bagi kehidupan berorganisasi, maka keberadaan arsip perlu mendapatkan perhatian khusus, sehingga keberadaan arsip di kantor benar-benar menunjukkan peran yang sesuai dan dapat mendukung penyelesaian pekerjaan yang dilakukan semua personal dalam organisasi.

Menurut Yuniarti, (dalam Azizah 2012: 380) arsip adalah naskah yang diciptakan atau dikumpulkan oleh suatu organisasi dalam rangka menjalankan fungsi dan kegiatannya dan disimpan oleh penciptanya karena arsip tersebut mempunyai kegunaan untuk kelanjutan administrasi atau untuk kegiatan penelitian. Sedangkan menurut UndangUndang No. 43 tahun 2009 tentang kearsipan, yaitu kearsipan adalah hal-hal yang berkenaan dengan arsip dan arsip juga merupakan rekaman kegiatan atau peristiwa dalam berbagai bentuk dan media sesuai dengan perkembangan teknologi informasi dan komunikasi yang dibuat dan diterima oleh lembaga negara, pemerintahan daerah, lembaga pendidikan, perusahaan, organisasi politik, organisasi kemasyarakatan, dan perseorangan dalam pelaksanaan kehidupan bermasyarakat, berbangsa, dan bernegara.

Dalam kegiatan berorganisasi, arsip mempunyai dua peranan yaitu, arsip sebagai sumbe $r$ informasi dan arsip sebagai sumber dokumen. Seb agai sumber informasi, arsip dapat digunakan oleh pimpinansuatu instansi untuk membuat keputusan secara tepat mengenaipersoalan yang dihadapi. Sed angkan arsip sebagai sumber dokumen dapat diingi nkan untuk mengingatkan pegawai yang lupa meng enai suatu persoalan yang menyangkut dengan arsi p, maka dari itu arsip sangat bermanfaat bagi kelangsungan dan kelancaran suatu organisasi atau instansi baik pemerintahan maupun swasta dan arsip harus di simpan dengan sebaik mungkin sehingga mudah untuk ditemu kembalikan. Menurut Asriel, (2018: 99) filling (penyimpanan) arsip merupakan kegiatan penataan dan penyimpanan arsip sedemikian rupa dengan menggunakan sistem penyimpanan tertentu dengan tujuan untuk mempermudah penemuan arsip kembali ketika dibutuhkan. Arsip juga merupakan bukti nyata dari kegiatan yang berlangsung di instansi. Arsip memiliki peranan dan nilai guna yang tinggi. Oleh sebab itu arsip harus dilindungi. Dan salah satu cara melindungi arsip, yaitu dengan cara penyimpanan arsip dengan sebaik mungkin dan dengan aturan yang telah ditentukan. Menurut Septia (dalam Rahayu 2014: 588), "Arsip merupakan sebuah informasi penting yang dibutuhkan setiap organisasi. Menurut fungsinya arsip digolongkan menjadi dua, yaitu arsip dinamis dan arsip statis, arsip dinamis merupakan arsip yang digunakan secara langsung dalam sebuah unit kerja. Oleh karena itu arsip perlu disimpan menggunakan sistem yang tepat, karena dipastikan arsip memiliki nilai guna penting yang menunjang kegiatan mereka". Penyimpanan arsip baik arsip dinamis aktif maupun inaktif yang baik dan benar bertujuan untuk memperlancar komunikasi dan tugas-tugas yang nantinya akan dikerjakan baik dalam sistem penyimpanan dan prosedur penyimpanannya. Menurut Sugiarto, (2015: 30) Prosedur penyimanan adalah langkah-langkah pekerjaan yang dilakukan sehubungan dengan akan disimpannya suatu dokumen. Menurut Asmida, (2018: 99) Prosedur Penyimpanan arsip dan penataan berkas dimulai dari penampungan (penerimaan) arsip, pemeriksaan arsip untuk diklasifikasikan, pengindeksan, pengkodean, penyimpanan arsip, dan penataan berkas.

Menurut Azizah ( 2012: 381-382) pemilihan peralatan yang digunakan untuk penataan berkas arsip aktif harus disesuaikan dengan bentuk fisik arsip, serta kebutuhan untuk penemuan kembalinya. dan dalam penyimpanan juga harus memperhatikan azas yang diterapkan dalam penyimpanan arsip. Ada 3 azas penyimpanan yaitu: pertama azas sentralisasi adalah proses pengelolaan arsip dinamis aktif yang dilaksanakan di satu ruangan sentral file untuk seluruh organisasi. Sistem pengelolaan arsip secara sentral ini hanya efesien dan efektif bila dilaksanakan pada kantor kecil, kedua azas desentralisasi adalah proses pengelolaan arsip dinamis aktif yang dilakukan oleh setiap unit kerja (major department) di dalam setiap organisasi dan yang terakhir azas kombinasi adalah gabungan dari sistem sentralisasi dan desentralisasi. Pada sistem ini, masing-masing bagian menyimpan arsip dinamis di bawah kontrol sistem terpusat. Tanggung jawab sistem berada di pundak petugas yang secara operasional bertanggung jawab atas arsip dinamis sebuah instansi atau lembaga. 
Perka ANRI Nomor 37 Tahun 2016 tentang

Menurut Barthos, (dalam Azizah 2012: 382) Pedoman Penyusutan Arsip, Perka ANRI Nomor 06 arsip dinamis adalah arsip yang masih diperlukan Tahun 2005 tentang Pedoman Perlindungan, secara langsung dalam perencanaan, pelaksanaan, Pengamanan dan Penyelamatan Dokumen/Arsip penyelenggaraan kehidupan kebangsaan pada Vital Negara, Perka ANRI Nomor 46 Tahun 2015 umumnya atau arsip yang digunakan secara tentang Penyelamatan Arsip Penggabungan atau langsung dalam penyelenggaraan administrasi Pembubaran Lembaga Negara dan Perangkat negara. Dari kegunaannya arsip dinamis dibedakan Daerah, Perka ANRI Nomor 29 Tahun 2011 tentang atas 2 macam, yaitu: pertama, arsip dinamis aktif Pedoman Penelusuran Arsip Statis di LIngkungan adalah arsip yang secara langsung dan terus Pencipta Arsip, Perka ANRI Nomor 09 Tahun 2018 menerus diperlukan dan digunakan dalam tentang Pedoman Pemeliharaan Arsip Dinamis, penyelenggaraan administrasi sehari-hari serta Perka ANRI Nomor 18 Tahun 2012 tentang masih dikelola oleh unit pengolah. Kedua, arsip Pedoman Pembuatan dan Pengumuman Daftar dinamis inaktif adalah arsip yang tidak secara Pencarian Arsip (DPA), Perka ANRI Nomor Nomor langsung dan tidak terus menerus diperlukan dan 26 Tahun 2016 tentang Pedoman Keterbukaan digunakan dalam penyelenggaraan administrasi Arsip Statis untuk Penelitian dan Pengembangan sehari-hari serta dikelola oleh pusat arsip. Menurut Ilmu Pengetahuan Serta Penyelidikan dan Sugiarto, (2015: 8) arsip dinamis adalah semua Penyidikan.

arsip yang masih berada di berbagai kantor, baik kantor pemerintah, swasta atau organisasi kemasyarakatan, karena masih dipergunakan secara langsung dalam perencanaan, pelaksanaan dan kegiatan administrasi lainnya.

Berdasarkan pengamatan selama PKL di Dinas Kearsipan dan Perpustakaan Kab. Padang Pariaman arsip yang disimpan di bidang kearsipan yaitu arsip dinamis aktif. Prosedur penyimpanan arsip dinamis aktif sudah sesuai dengan teori. Hal ini terlihat pada proses temu kembali arsip dimana arsiparis dengan mudah menemu kembali arsip yang dibutuhkan. Dalam proses penyimpanan arsip dinamis aktif di Dinas Kearsipan dan Perpustakaan Kab. Padang Pariaman menggunakan Norma, Standar, Prosedur dan Kriteria (NSPK) dalam Pelaksanaan Pemberkasan Arsip sebagai pedoman dalam pelaksanaan pemberkasan arsip di lingkungan Dinas Kearsipan dan Perpustakaan Kabupaten Padang Pariaman, dalam Penerapan petunjuk pelaksanaan pemberkasan arsip disesuaikan dengan kondisi unit kerja masingmasing terhadap hal-hal yang spesifik. Hal ini dibuat agar dapat memberikan kemudahan dalam penyimpanan dan penemuan kembali arsip yang mendukung penguatan tata kelola, akuntabilitas dan pencitraan publik di lingkungan Dinas Kearsipan dan Perpustakaan Kabupaten Padang Pariaman.

Dasar hukum terkait penyusunan NSPK di Dinas Kearsipan dan Perpustakaan Kabupaten Padang Pariaman yaitu: Undang-Undang Nomor 43 Tahun 2009 tentang Kearsipan, Peraturan Pemerintah Nomor 28 tentang Pelaksanaan Undang-Undang Nomor 43 Tahun 2009 tentang Kearsipan, Undang-Undang Nomor 7 tahun 1971 tentang Ketentuan-Ketentuan Pokok Kearsipan, keterkaitan dengan arsip lain. Kedua, Penyortiran,

Selain itu sarana dan prasarana untuk penyimpanan arsip dinamis aktif di Dinas Kearsipan dan Perpustakaan Kabupaten Padang Pariaman juga sudah memadai, meskipun masih banyak kekurangan dari segi tempat dan fasilitas. Berdasarkan uraian di atas, tujuan penelitan ini adalah untuk mendeskripsikan bagaimana prosedur penyimpanan arsip dinamis aktif di bidang kearsipan Dinas Kearsipan dan Perpustakaan Kabupaten Padang Pariaman dan untuk mendeskripsikan apa saja kendala yang dihadapi oleh bidang kearsipan Dinas Kearsipan dan Perpustakaan Kabupaten Padang Pariaman dalam penyimpanan arsip dinamis aktif.

\section{METODE}

Metode penelitian yang digunakan peneliti adalah metode penelitian kepustakaan dan studi lapangan, pengumpulan data dilakukan dengan cara pengamatan/observasi dan melakukan wawancara kepada pegawai di bidang kearsipan Dinas Kearsipan dan Perpustakaan Kabupaten Padang Pariaman untuk mengetahui penyimpanan arsip dinamis aktif di bidang kearsipan Dinas Kearsipan dan Perpustakaan Kabupaten Padang Pariaman.

\section{HASIL DAN PEMBAHSAN}

\section{Prosedur Penyimpanan Arsip Dinamis Aktif di bidang kearsipan Dinas Kearsipan dan Perpustakaan Kabupaten Padang Pariaman}

Berdasarkan pengamatan penulis prosedur penyimpanan arsip dinamis aktif bidang kearsipan Dinas Kearsipan dan Perpustakaan Kabupaten Padang Pariaman adalah: Pertama, pemeriksaan, dilakukan untuk mengetahui tanda simpan, kelengkapan arsip, kondisi fisik arsip dan 
Menurut Sugiarto, (2015: 32) menyortir adalah mengelompokkan dokumen-dokumen untuk persiapkan ke langkah terakhir yaitu penyimpanan. Penyortiran dilakukan untuk memilah antara kelompok arsip yang satu dengan kelompok arsip yang lain atau memisahkan duplikat-duplikat yang tidak berguna, misalnya arsip surat masuk surat keluar, peraturan bupati, arsip pembinaan kearsipan akan dikelompokkan masing-masing jenisnya di bidang kearsipan.

Ketiga, Penentuan indeks, dilakukan untuk menentukan nama jenis arsip atau kata tangkap (caption) atau kata kunci (keyword) sesuai dengan materi arsip. Menurut Sugiarto, (2015: 31) Mengindeks adalah pekerjaan menentukan pada nama apa atau subyek apa, atau kata- tangkap lainnya, surat akan disimpan.

Menurut Sugiarto, (1997: 34-36) prosedur penyimpanan arsip adalah langkah-langkah pekerjaan yang dilakukan sehubungan dengan akan disimpannya suatu dokumen. Langkah-langkah atau prosedur penyimpanan arsip ini yaitu pemeriksaan, mengindeks, memberi tanda, menyortir, dan yang terakhir menyimpan. Pertama, pemeriksaan, ini bertujuan untuk memastikan bahwa surat surat tersebut sudah siap untuk disimpan. Kedua, setelah melakukan pemeriksaan, seorang petugas arsiparis harus melakukan pengindeksan, mengindeks adalah pekerjaan menentukan kata tangkap pada surat yang akan disimpan. Kegiatan ini bertujuan untuk mempermudah temu kembali arsip dengan tanda pengenal atau kata tangkap pada warkat. Kata tangkap dapat berupa nama orang, nama badan, nama tempat, istilah subjek, atau angka, tergantung pada sistem penyimpanan yang dipergunakan. Indeks atau kata tangkap untuk arsip dinamis aktif di bidang kearsipan menggunakan indeks subyek dalam penyimpanannya.

Keempat, Penentuan kode dilakukan berdasarkan kelompok masalah, sub masalah, dan sub-sub masalah. Kode merupakan tanda pengenal arsip sesuai klasifikasinya. Penentuan kode arsip di bidang kearsipan Dinas Kearsipan dan Perpustakaan Kabupaten Padang Pariaman yaitu pertama, perhatikan bentuk kode yang digunakan dalam klasifikasi arsip, kedua, untuk menentukan kode perlu membaca isi surat dan menggolongkan informasinya pada masalah pokok, sub masalah, dan sub-sub masalah, ketiga, menuliskan kode klasifikasi arsip pada indeks yang ditentukan pada secarik kertas yang ditempelkan pada berkas.

Kelima, Pembuatan label, dilaksanakan pada sekat penunjuk (guide), folder/map, dan peralatan penyimpan arsip lainnya yang dilaksanakan secara konsisten. Pembuatan label untuk arsip dinamis aktif di bidang kearsipan dibagi atas 3 yaitu label primer, sekunder dan teriser yang diletakan pada sekat penunjuk (guide). Keenam, Penempatan arsip dilakukan sesuai dengan lokasi atau kelompok subjeknya. langkah ini harus dilakukan secara teliti dan hati-hati. Jangan sampai terjadi kesalahan penempatan arsip yang dapat mengakibatkan hilangnya suatu dokumen. Bila terjadi kesalahan letak arsip dinamis aktif di filling cabinet, maka semua tahap menyortir dapat dikatakan sia-sia.

Dalam penyimpanan arsip dinamis aktif terdapat sarana dan prasana dalam menunjang kegiatan penyimpanan arsip, sarana dan prasarana arsip di bidang Kearsipan adalah Filing cabinet adalah sarana penyimpanan arsip aktif yang terbuat dari bahan plat besi/baja yang bentuknya berupa laci yang tersusun secara vertikal. Lemari arsip adalah sarana penyimpanan arsip yang terbuat dari bahan besi dengan susunan secara lateral. Guide atau sekat alat yang terbuat dari karton/triplek yang digunakan sebagai pembatasan/penyekat arsip. Sekat ini mempunyai tab/tempat label yang letaknya disesuaikan dengan kebutuhan baik diatas maupun di samping. Folder adalah sarana berupa map untuk tempat menyimpan arsip terutama arsip tekstual. Folder juga mempunyai bagian yang menonjol yang dinamakan tab pada bagian atas atau bagian kanan bawah sesuai dengan kebutuhan pengguna. Klasifikasi dan kode sebagai sarana/ perangkat lunak untuk menentukan kelompok berkas dan kode masalah sesuai dengan isi informasi yang terkandung dalam arsip. Indeks sebagai sarana/perangkat lunak yang merupakan identitas atau tanda pengenal berkas.

Jadi, prosedur penyimpanan yang dilakukan bidang kearsipan Dinas Kearsipan dan Perpustakaan Kabupaten Padang Pariaman sudah melalui semua tahapan dalam penyimpanan arsip dinamis aktif, dari hasil wawancara dengan pegawai bidang kearsipan bahwa penyimpanan arsip dinamis aktif sudah dilakukan sesuai pedoman yang disusun berdasarkan NSPK di Dinas Kearsipan dan Perpustakaan Kab. Padang Pariaman sehingga memudahkan arsiparis dalam penemuan kembali arsip di lingkungan Dinas Kearsipan dan Perpustakaan Kabupaten Padang Pariaman dengan cepat, tepat, aman dan efisien.

\section{Kendala Penyimpanan Arsip Dinamis Aktif}

Adapun kendala yang dihadapi pegawai bidang kearsipan di Dinas Kearsipan dan Perpustakaan Kabupaten Padang Pariaman dalam 
penyimpanan arsip dinamis aktif yaitu pertama, kurangnya SDM (Sumber Daya Manusia), Penyimpanan arsip dinamis aktif di bidang kearsipan sudah melakukan tahapan atau prosedur penyimpanan yang sesuai dengan teori serta sarana dan prasaran yang memadai, akan tetapi arsiparis bidang kearsipan di Dinas Kearsipan dan Perpustakaan Kabupaten Padang Pariaman belum mamadai yaitu masih terdiri dari 3 orang, 1 orang pegawai dan 2 orang yang dikontrak, seharusnya dengan keadaan arsip yang sangat banyak di Dinas Kearsipan dan Perpustakaan Kabupaten Padang Pariaman sangat membutuhkan lebih banyak arsiparis dalam melakukan penyimpanan arsip dinamis aktif, karena arsiparis yang bertugas dalam penyimpanan arsip dinamis aktif harus dikelola oleh satu orang arsiparis saja, dan arsip-arsip tersebut harus di simpan sesuai prosedur oleh orang yang berkompeten di bidangnya, karena Dinas Kearsipan dan Perpustakaan Kabupaten Padang Pariaman merupakan sebuah lembaga pemerintah yang wajib mengatur, menyimpan, memelihara dan menyelamatkan arsip. Untuk memenuhi kewajiban tersebut maka diperlukan tenaga pengelola arsip di lingkungan Dinas Kearsipan dan Perpustakaan Kabupaten Padang Pariaman.

Kedua tempat yang kurang memadai, Dinas Kearsipan dan Perpustakaan Kabupaten Padang Pariaman belum memiliki bangunan sendiri, bangunan yang ditempati Dinas Kearsipan dan Perpustakaan Kabupaten Padang Pariaman saat ini adalah bangunan Dinas Pendidikan Padang Pariaman yang lama sehingga ruangan dalam penyimanan arsip dinamis aktif belum di rancang sesuai dengan prosedur. penyimpanan arsip dinamis aktif bidang kearsipan di simpan dalam ruangan tempat pegawai bekerja terdapat meja kepala bidang, meja KASI, meja pegawai lainya, dalam ruangan tersebut juga terdapat ruangan alih media arsip sehingga dengan keadaan ruangan yang kurang memadai akan membuat arsiparis kesusahan dalam proses penyimpanan arsip. Pada proses penyimpanan arsip seperti pemeriksaan arsip, penyortiran dan pengindeksan dilakukan arsiparis di meja pegawai hal ini akan membuat para pegawai terganggu dengan kegiatan tersebut dan juga arsiparis mengalami kesulitan dalam melakukan tahapan penyimpanan arsip dinamis aktif dan berkemungkinan besar juga terjadi kecelakaan kerja, karena prosedur penyimpanan tidak dilakukan di ruangan khusus melainkan di ruangan tempat para pegawai bekerja.

\section{SIMPULAN}

Berdasarkan penjelasan pada pembahasan bahwa dalam penyimpanan arsip dinamis aktif di bidang kearsipan Dinas Kearsipan dan Perpustakaan Kabupaten Padang Pariaman sudah berjalan sesuai prosedur atau Norma, Standar, Prosedur dan Kriteria (NSPK) di Lingkungan Dinas Kearsipan dan Perpustakaan Kabupaten Padang Pariaman dimana prosedur penyimpanan arsip terdiri dari pemeriksaan, penyortiran, penentuan indeks, penentuan kode, pembuatan label, dan penempatan arsip. Penyimpanan arsip dinamis aktif sudah dilakukan sesuai pedoman yang disusun berdasarkan NSPK di Dinas Kearsipan dan Perpustakaan Kab. Padang Pariaman sehingga memudahkan arsiparis dalam penemuan kembali arsip di lingkungan Dinas Kearsipan dan Perpustakaan Kabupaten Padang Pariaman dengan cepat, tepat, aman dan efisien. Ada beberapa kendala yang dihadapi dalam penyimpanan arsip dinamis aktif yaitu pertama, kurangnya SDM (Sumber Daya Manusia) dalam penyimpanan arsip dinamis aktif, karena Dinas Kearsipan dan Perpustakaan Kabupaten Padang Pariaman merupakan sebuah lembaga pemerintah yang wajib mengatur, menyimpan, memelihara dan menyelamatkan arsip. Untuk memenuhi kewajiban tersebut maka diperlukan tenaga pengelola arsip di lingkungan Dinas Kearsipan dan Perpustakaan Kabupaten Padang Pariaman. Kedua tempat yang kurang memadai, karena Dinas Kearsipan dan Perpustakaan Kabupaten Padang Pariaman belum memiliki bangunan sendiri, bangunan yang ditempati Dinas Kearsipan dan Perpustakaan Kabupaten Padang Pariaman saat ini adalah bangunan Dinas Pendidikan Padang Pariaman yang lama sehingga ruangan dalam penyimpanan arsip dinamis aktif belum di rancang sesuai dengan prosedur.

\section{DAFTAR PUSTAKA}

Azizah, Mardiah. 2012. Penyimpanan Arsip Dinamis Aktif Di Bagian Tata Usaha Sma Pertiwi 1 Kota Padang Jurnal Ilmu Informasi Perpustakaan dan Kearsipan Vol. 1, No. 1, September2012.

Asriel, Armida Silvia. 2018. Manajemen Kearsipan. Bandung: Remaja Rosdakarya

Indonesia. Undang-Undang Republik Indonesia Nomor 43 Tahun 2009 Tentang Kearsipan. Jakarta: Arsip Nasional Republik Indonesia.

Rahayu, S. H. Pudji. 2014. Pengelolaan Arsip Dinamis Dalam Meningkatkan Sistem Informasi Manajemen Di Kantor Perpustakaan Dan Arsip Daerah Kabupaten BanjarnegaraEconomic Education Analysis 
Journal 3 (3) (2014).

Sugiarto, Agus dan Teguh Wahyono. 2015.

Manajemen Kearsipan Modern. Yogyakarta:

Gava Media.

Sugiarto, Agus dan Teguh Wahyono. 1997.

Manajemen Kearsipan Modern. Yogyakarta:

Gava Media. 